Street there is one from Hythe; all of the specimens that I have seen (i.e., all except those at the British Muselm) are in a similar matrix. This Polyzoon is the most characteristic fossil of the horizon; portions of the rock appear to be entirely permeated by it.

I am indebted to Dr. J. W. Gregory, F.G.S., entirely for the names of the three Polyzoa ; and to Mr. E. T. Newton, F.R.S., for assistance with the other identifications.

\title{
NOTES ON THE SHARKS' TEETH FROM BRITISH CRETACEOUS FORMATIONS.
}

BY A. SMITH WOODWARD, F.G.S., of the British Museum (Natural History).

[iread Friday, rst December, 1893.]

TH $\mathrm{HE}$ specific determination of the detached teeth of sharks and skates is little more than guess work; and to decide upon their generic relationships with any approach to certainty is also often very difficult. The teeth vary so much in form and proportions in different parts of the mouth, and some well-defined genera and species differ so little from one another in their dentition, that a scientific nomenclature is sometimes quite impossible. Such teeth, however, are anong the commonest fossils in many Cretaceous and Tertiary formations, and it is therefore desirable to attempt to give them provisional names. The result may sometimes express an actual fact-sometimes quite the reverse; but, at any rate, for purposes of correlation it is convenient to have a name for each distinguishable form of tooth. So tar as possible, allowance must be made for variation to the extent observed in the jaws of the most nearly related existing genera ; and whenever a group of fossil teeth is discovered, evidently belonging to one mouth, the problem of determination is still further simplified.

With this preface, we propose to briefly review our present knowledge of the Selachian teeth met with in British Cretaceous formations, making special reference to those of the still-existing family of Lamnidæ. Such a review, illustrated by the accompanying plates, may prove of value to collectors; while several of the specimens described will add a little of importance to the facts already known. The paper is shortened as much as possible by the omission of references to the literature of the subject, these having been fully given, up to the year 1890 , in Woodward and Sherborn's Catalogue of British Fossil Vertebrata.

Ferruary, 1894.] 


\title{
SUB-ORDER TECTOSPONDYLI.
}

\author{
FaMILY SQUATINIDAE.
}

\section{Genus Squatina.}

The occurrence of extinct "Monk-fishes," or "Angel-fishes," apparently of the still-existing genus Squatina, in the English Chalk, was recorded on a former occasion ;* but all of the species except one (S. Cranei) are known merely from detached teeth, and are therefore incapable of specific determination. Three characteristic teeth, which will illustrate the brief description previously given, are shown of the natural size in Pl. v, figs. I-3, all eshibiting the outer aspect; and a lower view of the expanded base of the third specimen is added in fig. $3 a$. The original of fir. I was obtained from the Gault of Folkestone, and is probably an anterior tooth; figs. 2 and 3 represent specimens from the Lpper Chalk of Sussex.

\section{Family $M Y L I O B A T I D A E$ (?).}

\section{Grenus Ptychodus.}

A general account of the common Upper Cretaceous teeth named Ptychodus, with observations on their arrangement in the mouth, was given in the author's earlier paper already quoted : $\dagger$ and no discoveries of importance have been subsequently made. 'There are, however, two very rare forms of teeth in the English Cretaceous, to which it may be well to direct special attention; and collectors would do good survice by making known any specimens of this character with which they happen to be acquainted.

I. Ptychodus Mortoni, Mantell (Pl. v, fig. 4). This form of tooth is remarkable from the circumstance that the principal ridges of the crown are not transverse, but radiate fron a central point. It was first discovered in the Cretaceous of Alabama, where it seems to be a common fossil ; and there is a large, naturally-a-sociated group of teeth of this species, from the Chalk of Kansas, in the Yale University Museum, showing all the various shapes and sizes of teeth met with in a single mouth of the typical species of the genus. The small upper median teeth are not marked with the radiating ridges, but exhibit a minute smooth eminence in the middle of the crown. Most of the English specimen:, however, ascribed to P. Mortoni in collections, are truly the upper median teeth of other spacies; and it is thus of interest to find a single tooth from the Chalk of Winchester which is so characteristic that its close resemblance to the American specimens

* A. S. Wootward, "A Synopsis of the Vertebrate Fossils of the English Chalk, Proc. Geol. Assoc,, vol. x (1888), p. 294.

$\dagger$ Loc. cit., pp. $294^{-298}$, fig. 3 . 
cannot be overlooked 'This fossil, displaying the centre of the crown but not the whole of the border, is shown of the natural size in Pl. v, fig. 4, and is now in the Oxford Museum.

2. Ptychodus levis, sp. nov. (Pl. v, figs. 5, 6). 'Two small teeth in the British Museum from the Lower Chalk and Grey Chalk of Kent differ so nuch from those of all known species, that we propose to distinguish them by a new name. Though not showing any signs of abrasion, they are remarkably smooth; and the moderately elevated median area of the crown is marked by very feeble transverse ridges and furrows, passing gradually at the extremities into the still more delicate striations of the marginal area, which are chiefly radiating. They most resemble the teath of $P$. decurrens, but are much more finely ornamented; and the nature of the external layer of the crown is such that it becomes very dark when fossilised. The first specimen (fig. 5) seems to belong either to one of the three median series of the lower dentition or to the innermost paired upper series, and was discovered by Mr. S. T. Hawkins, F.G.S., in the I.ower Chalk of Blue Bell Hill, Burham; the second tooth (fig. 6) would occury a more lateral position in the mouth, and was obtained from the Grey Chalk of Dover.

\section{StiB-ORDER ASTEROSPONDYLI.}

\section{FAMILY NOTIDANID.E.}

\section{Genus Notidanus.}

The writer has already sufficiently described the English Cretaceous teeth of Notidamus, ${ }^{*}$ and no form differing from the typical $N$. microdon (Pl. $v$, figs. 7,8 ) has been discovered since that description. The new figures of lower teeth here given may' prove useful for comparison; and it may be added, in reference to the supposed distinct tooth named $N$. pectinatus by Agassiz, that the discovery of specimens showing much larger anterior serrations than those here indicated, is especially to be desired.

\section{FAMILY CESTRACIONTIDAE. \\ Genus Synechodus.}

Since I 888, when the generic name Synechodus was first proposed for the small Hybodont teeth from the English Chalk, $\uparrow$ much new information has been obtained concerning the shark they represent. A complete summary will be found in the British Museum Catalogue of Fossil Fishes, Part I, and in a subsequent paper published in $1892 .+$ It will thus suffice on the

* Loc. cit., p. 287.

+ Loc. ci', p+ 287 .

+A.S. Wootward, "The Hybolon and Cestraciont Sharts of the Creatceuss Period, Proc, Forks. Geol. and l'olvt. Soc., vol. xii (18)2), p. 62, Pli. i, ii. 


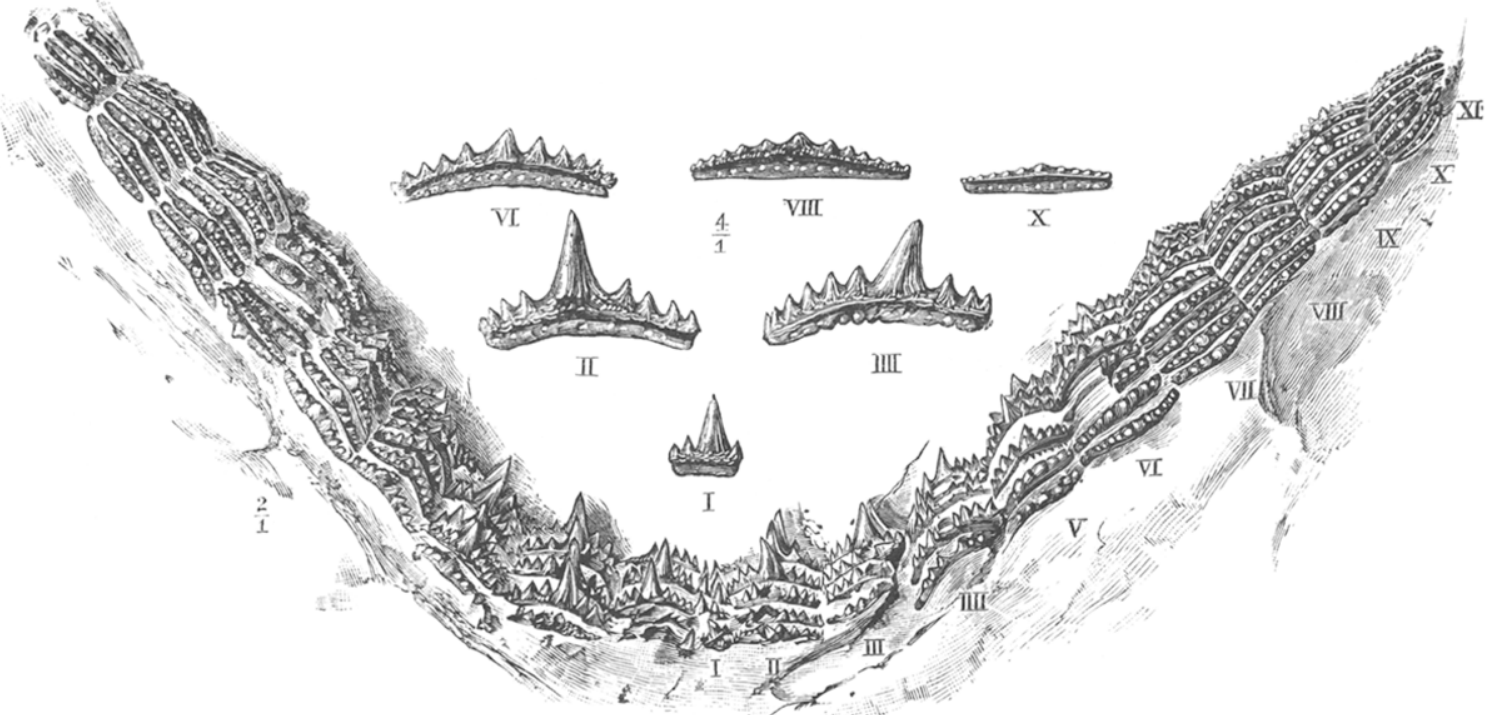

Fig. I.-Dexrtron of Synechodus dubrisiensis, MaCkie si'; Chalk, Sussex.

[Collection of HEnry Wallott, Eisq, F.G.S., Brightor MIuseum.] 
present occasion to append a figure of the dentition of the type species, S. dubrisiensis (p. 193, fig. I), for convenience of reference. The teeth themselves cannot be distinguished from those of the well-known Jurassic Hybodus; but the fish differs from the latter genus in having well-calcified vertebræ and smooth dorsal fin. spines. The typical Hybodus, with notochordal skeleton, cephalic spines, and ribbed fin-spines, is known to occur in the IVealden (H. basanus), but has not been detected with certainty in any later deposit.

\section{Genus Acrodus.}

The Gault of Folkestone yields typical teeth of this genus, which are remarkably smooth, and hence narned Acrodus levis. The two type specimens are shown of twice the natural size in the accompanying woodcut (fig. 2), for the loan of which we are indebted to the Editor of the Geological Magasine. Only one doubtful tooth has been found in the Chalk, and it is now almost certain that the so-called Acrodus Illingzorthi is a large Synechodus.
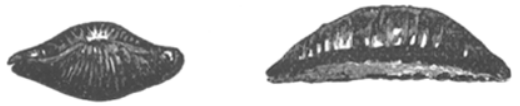

Fig. 2.-TeEth of Acrodus leqis, A. S. Woomw, Gault, Folkestone.

\section{Genus Cestracion.}

The Cretaceous shark described on the former occasion* as Drepanephorus, proves, on careful comparison, to exhibit no essential differences from the existing Port Jackson Shark, Cestracion; and the so.called $D$. canaliculatus and $D$. rugosus have thus been assigned to Cestracion in the British Museum Catalogue. The relatively large teeth of the last-named species still seem to be very rare. The latest discovered specimen noticed by the present writert was obtained by Mr. G. E. Dibley from the Lower Chalk of Warlingham, Surrey.

\section{Genus Gomphodus.}

The name of Gomphodus Agassizi was given by Reuss to some small teeth from the Cenomanian of Bohemia, much resembling the anterior prehensile teeth of Cestracion. Their affinities, however, are still uncertain, and figures of two English specimens are given here (Pl. v, figs. 9, 10) to direct the attention of collectors to them. The original of fig. 9 has much smaller lateral denticles than that of fig. 1o, and the first exhibits most rugosity at the base of the crown; both were obtained lrom the Upper Chalk of Kent.

* I' oc. Cieol. Asrot., vol. x, pp. 288-29o.

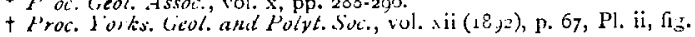


FAMILY SCYLLIIDA.

Some minute Odontaspis-shaped teeth from the English Chalk doubtless belong to small dog-fishes of the family Scylliidæ, and the discovery of skeletons with fins is necessary to determine whether or not the specimens from the Lower Chalk of Kent named Scyllium antiquum and S. dubium are correctly determined. 'The only remains described at the time of the writer's last "synopsis" (loc: cit., p. 293) were known as Scylliodus antiquus, and it has subsequently been proved that two very distinct fishes were confounded in the original determination. The smaller of these is the fish just mentioned under the name of Scyllium antiquum; the larger is the type of the genus Cantioscyllizm.

\section{Genus Cantioscyllium.}

The reason why this larger fish can now be distinguished from the smaller is, that by clearing away the matrix the teeth have been exposed. They are shown of twice the natural size in Pl. vi, fig. $r$, and are evidently quite distinct from those of Scyllium. The dental crown consists of a single elevated principal cone, with one or two pairs of small lateral cones; and the anterior face is produced downwards and forwards mesially, while it exhibits conspicuous striations. Only one specimen is known, the original Cantioscyllium decipiens, from the Lower Chalk of Burham, in the British Museum.

\section{FaMILY $L A M N I D A$.}

The teeth of this family are all solid when completely formed, and those of the principal genera are relatively large, more or less compressed, lanceolate, and pointed, adapted for lacerating.

The Lamnidxe are represented in the English Cretaceous formations by at least four genera, of which two seem to be still living.

\section{Genus Scapanorhynchus.}

A number of small teeth met with in European Cretaceous formations cannot be distinguished from those of the existing genus Odontaspis; and they were originally described under this name by Agassiz. Precisely similar teeth, however, were discovered a few years ago in sharks from the Upper Cretaceous of Mount Lebanon, which are preserved as complete fishes, showing all the fins, and can readily be recognised as quite distinct both 1rom Odontaspis and from other living genera. They are named Scapanorhynchus, in allusion to their long shovel-shaped snout. Instead, therefore, of retaining the British Cretaceous teeth in the genus Odontaspis, it seems more philosophical to refer them to the only known contemporaneous form of shark possessing 
exactly similar teeth; and we now provisionally recognise three species of Scapanurlynchus in the Cretaceous rocks of the S.E. of England. There is some evidence of a fourth species in the Neocomian, but that as yet is unsatisfactory.

I. Sapanorhy'uchus rhaphiodon, Agassiz sp. (PJ. v, figs. I 1-13). The teeth of this form are readily distinguished by the sharp and conspicuous striations on the inner (convex) face of the crown. The anterior teeth, of which one is shown from the external aspect in fig. II, and another from the internal aspect in fig. 12, are destitute of lateral denticles; but all the posterior teeth, as shown in fig. I 3 , have a single pair of well-developed acuminate denticles. The species ranges from the Upper Greensand to the uppermost Chalk of Norwich.

2. Scapanorhynchus subulatus, Agassiz sp. (Pl. v, figs. I 4, 15). The reference of this species to Scapanorhy'nchus is more problematical than that of the foregoing; and it is likely that many of the teeth commonly placed here are incorrectly associated with the type of Agassic. So far as the present writer can judge, the specific name ought to be confined to teeth of the form shown in Pl. v, figs. I 4, I5, and such are found in England to range from the Gault to the Upper Chalk. The lateral denticles are larse: and robust in all the teeth, and the inner face of the crown is always smooth.

3. Salpanorlynchus pigras, A. S. Woodw. (Pl. v, figs. I6-18). 'The present writer has suggested this name for the comparatively' large teeth shown in Pl. v, figs. $16-18$. They are very slender, often sigmoidally curved, and have sharp edges; the outer face of the crown is flat, except in the anterior teeth, and the inner face is smooth : the crown is somewhat expanded laterally at the base, the sharp edges extending to its inferior limit. Lateral denticles are absent or merely asperities in the anterior teeth, very minute in the others. The species is known only from the Cambridge Greensand.

\section{Genus Oxyrhina.}

The name Oryrlina is given to teeth of Jamnidx with smooth edges, and destitute of lateral denticles. A shark with similar teeth still exists, and it proves to be scarcely distinguishable from the typical Lamna.

Four species bave been recorded from English Cretaceous formations, namely, $O$. Mantelli, crassidens, angustidens, and macrorhiza; and of these the teeth of the first two have been well figured." 'The third and fourth species bave merely been recorded, no figures of British specimens having hitherto been published. The deficiency is therefore now supplied.

* For drawings of a series of teeth of Oxyrhina . Mantelli from one mouth, see Catal. Foss. Fishes Brit. MIus., pt. i, Pl, xvii, figs. g-21. 
I. Oxyrhina angustidens, Reuss (Pl. v, figs. 20-23). These are small teeth known only from the Upper Greensand to the Lower Chalk. They have a very narrow crown with expansion at the base, quite smooth as usual; and in the anterior teeth (fig. 2o) the branches of the root are considerably elongated.

2. Oxyrhina macrorhiza, Pictet and Campiche (Pl. v, fig. 24). The teetl of this form are very robust and narrow, with the root greatly developed and produced inwards, as well shown in side-view (Pl. v, fig. 24). They appear to be restricted to the Gault and Cambridge Greensand.

\section{Genus Lamna.}

A careful review of the fossil teeth named Otodus by Agassiz, has convinced most modern authors that the majority must be referred to Lamna; at leas', that the teeth themselves do not justify their separation from the last-named existing genus. It may be doubted whether the typical Otodus obliquus of the Eocene, Olodus sulcatus of the Chalk, and the large robust teeth described below as Lamna semiplicata are correctly placed here; but in reference to such species as $L$. appendiculata there need be little hesitation. Figures of four of the five British Cretaceous species are now given, with the addition of a French species which will probably be discovered in the Norwich Chalk.

I. Lamna appendiculata, Agassiz (Pl. v, fig. 25 ; Pl. vi, fig. 2). This seems to be the commonest species met with in Cretaceous formations and ranges from the Gault upwards. The teeth are very variable in form, and the accompanying figures give for the first time a precise idea of the limit to which this variation may extend in a single mouth. The fourteen teeth shown in Pl. v, fig. 25, are taken from a naturally-associated group of twenty-five teeth from the Chalk of Maidstone; while the twelve specimens represented in $\mathrm{Pl}$. vi, fig. 2, are from a still larger group of about sixty teeth found associated in the Lower Chalk of Dover. Both groups show the same variation, exactly agreeing with that to be observed in the dentition of a modern Lamna; and both are of great interest as exhibiting a diminutive robust tooth $(j)$ which corresponds precisely with one of the dwarfed teeth always met with in the recent Lamna in the upper jaw immediately beyond the third tooth from the symphysis.

2. Lamna semiplicata, Agassiz sp. (Pl. vi, figs. 3, 4). The form of tooth here figured was first recorded from the English Chalk in the writer's previous paper of 1888 , and only two specimens are known. The crown is broad and moderately compressed, with a single pair of very broad lateral denticles, sometimes incompletely subdivided; and both faces exhibit vertical wrinkles at the base.

3. Lamna sulcala, Geinitz sp. A name given to very large 
robust teeth with vertically wrinkled crown and slightly divergent, acuminate lateral denticles. There are specimens in the British Museum from undetermined horizons in the Chalk of Kent, Surrey, and Sussex.

4. Lamna macrorkiza, Cope (Pl. vi, figs. 5-9). Numerous teeth of small size of the form shown in the accompanying figures, occur in the English Gault, and they appear to be identical with specimens described by Prof. Cope from the Niobrara Formation of Kansas, U.S.A. They have an elevated narrow crown, wrinkled at the base, with large, very divergent, acuminate lateral denticles.

5. Lamna arcuata, sp. nov. (Pl. vi, fig. 10). Two teeth from the Upper Chalk of Norwich appear to 1epresent a new species, of which there is evidence also in the corresponding horizons of Maastricht and Ciply on the continent. A typical specimen is shown from the outer aspect in PI. vi, fig. Io. The crown is moderately compressed, smooth, acute and narrow, and somewhat bent in the principal hinder teeth; a single pair of large, acuminate lateral denticles is present, and the root is relatively small.

6. Lamna serra, A. S. Woodw. (Pl. vi, figs. 11, I2). The teeth thus named, as already mentioned, are merely noticed here in reference to their possible discovery in the Norwich Chalk. They are as yet known only from the Upper Chalk of Mont Aimé, France. The crown is much compressed, elevated, and smooth, with a single pair of broad, acuminate lateral denticles, and one or two smaller outer pairs; the root is short, and the inner nutritive foramen is situated in a groove.

\section{Genus Corax.}

Three forms of the familiar serrated teeth known as Corax are now recognised in English Cretaceous formations, the first ranging from the Cambridge Greensand upu ards, the others confined to the uppermost Chalk.

I. Corax falcatus, Agassiz (Pl. vi, figs. 13-15). Though having so wide a range, the largest teeth of this species are found only in the Chalk, and three typical examples are shown in the accompanying figures. The serrations on the nargin of the crown in the small (young) teeth are sometimes wanting.

2. Corax pristodontus, Agassiz (Pl. vi, figs. J6-- I8). The teeth thus named are of a comparatively large size, and scarcely distinguishable from $C$. falcatus, except in the greater relative width of the crown and the usually more convex form of its anterior margin. Only one naturally-associated set of teeth bas hitherto been discovered, and that in the Upper Senonian or Danian of Ciply, Belgium.*

* A. S. Woodward, "The Fish-fauna of the Danian of Ciply." Geol. Mag. [3], vol, viii (1891), p. r12, $\mathrm{Pl}$, iii, figs, to-16. 
3. Corax affinis, Agassiz (Pl. vi, figs. 19-22). 'The third species of Corax was confounded with $C$. falcatus by the present writer in $\mathbf{1} 888$, but the series of figures now given will serve to render its distinction simple. The crown is slender, smooth or very feebly serrated, notched prominently at the base of the hinder margin, and less so upon the anterior margin, thus producing a broad posterior denticle and a less distinct anterior denticle. The only known English specimens were obtained from the uppermost Chalk of Norwich.

\section{Family Carchariidæ.}

In conclusion, it may be added that no teeth of Carchariida have hitherto been discovered in the English Cretaceous, and, notwithstanding several records on the continent, it is still very uncertain whether there is any evidence of their existence in Cretaceous times. Most of the teeth are indistinguishable from those of Lamnidæ in external form, but they may be known by possessing an internal cavity even when fully developed. Any peculiar serrated teeth that may be met with are especially worthy of examination in reference to the latter point ; for it can hardly be supposed that Carcharias and its allies are an exclusively Tertiary group.

\section{EXPLANATION OF PLATES.}

Plate V.

FIG. I.-Syualina sp.; tooth, outer aspect.-Gault; Folkestone. (B. M., No. 47120.$)$

FIG. 2.-Squatina sp.; tooth, outer aspect.-U. Chalk ; Brighton. (B. M., No. 25768.)

FIG. 3.-Squatima sp.; tooth, outer and inferior (3a) aspert.-U. Chalk; Lewes. (B. M., No. P. 5322.)

FIG. 4-Piychodus Mortoni, Mantell ; tooth, portion of upper aspect.-Chalk ; Winchester. (Oxford University Museum.)

FIG. 5 -Ptychodus levis, sp. nov.; tooth, upper aspect.-L. Chalk; Blue-bell Hill, Burham. (B. M., No. P. 6524.)

FIG. 6.-Ditto ; ditto.-Grey Chalk ; Dover. (B. M., No. P. 5I.)

FIG. 7.-Notidanus microdon, Agass.; tooth, outer aspect.-Chalk ; Sussex. (B. M., No. 25793.)

FIG. 8.-Ditto; tooth, inner aspect.-U. Chalk; Norwich. (B. M., No. 24927.)

FIG. 9.-Gomphodus sp. ; tooth, outer and inner ( $9 a$ ) aspects. - Chalk ; Gravesend. (B. M., No. 41702.)

FIG. 10.-Gomphodus sp.; tooth, outer aspect, thrice natural size.-Chalk; Ctaring, Kent. '(B. M., No. P. 334.) 
FiGs. I1, I2.-Scapanorhynchus rhaphiodon, Agass, sp.; two anterior teeth, outer (II) and inner (I2) aspects.-Chalk; Kent. (B. M., Nos. P. 404,43080 .)

FIG. 13.-Ditto; posterior tooth, inner aspect.-U. Chalk; Shalford, near Guildiord. (B. M, No.49952.)

Fic. 14.-Scapanorhynihus (?) subulatzs, Agass. sp. ; anterior tooth, onter aspect.-Chalk; Halling, Kent. (B. M., No.41707)

FIG. 15.-Ditto; posterior tooth, outer aspect-Chalk; Arundel. (B. M, No. 49949.)

FIGs. 16-18.-Scupanorhynchus (?) gigas, A. S. Woo Jw.; three anteilor teeth, outer (I6), lateral (I7), and inner (I8) aspects. - Cambridge Greensand ; Cambridge. (B. M., No. 46362.)

FiG. I9.-Oxyrhina angustidens, Reuss (?); tooth, outer aspect-Cambridge Greensand ; Cambridge. (B. M., No. 46362 .)

FIG. 20.-Ditto; anteriur tooth, outer aspect.-Chalk; Halling. (B M., No. 4 [707b.)

FIG. 2I.-Ditto; tooth; outer aspect.-L. Chalk; Blue-bell Hill, Burham. (B. M., No. P. 6522.)

FIG. 22.-Ditto; tooth in matrix, inner aspect.-Chalk; Cherry Hinton, Cambridgeshire. (B. M., No. P. $238 \mathrm{I}$.)

FIG. 23.-Ditto; two teeth in matrix, outer aspect.-Chalk; Glynde, near Lewes. (B. M., No. 49948.)

FIG. 24.-Oxyrhina macrorhiza. Pict. \& Camp.; tooth, lateral aspect.-Cambridge Greensand ; Cambridge. (B. M., No. 35128.)

FiG. 25, a-o.-Lamna appendiculata, Agass, ; fourteen associated teeth.Chalk; Maidstone. (B. M., No. 39053.)

\section{Pi.ate VI.}

FIG. I.-Cantioscylizum decipiens, A. S. Woodw, ; four associated tet th: three $(a, b)$ from outer aspect, one $(c)$ seen from below, twice natural size. L. Chalk; Burham. (B. M., No. P. $5^{890}$.)

Fig. 2, a-m.-Lamna appendaculata, Agass; twelve associated teeth - L. Chalk; Dover. (B. M., No. P. 45.)

Fig. 3.-Lamna semiplicata, Agass, sp ; imperfect tooth, outer aspect.-L. Chalk; Rochester. (B. M, No. 43514.)

liIG. 4-Ditto; tooth in matrix, from outer and inner (4a) aspects.- L. Chalk; Charing, Kent. (B. M., No. P. 327.)

Figs. 5-9.-Lamna macrorhiza, Cope; teeth in matrix, all outer aspect except fig. 7.-Gault ; Folkestone. (B. M., Nos. 472 I $8 b$, P. I $2 a, b$.)

FiG. IO-Lamna arcuata, sp. nov.; tooth, outer aspect.-U. Chalk; Norwich. (B. M., No. 48956 b.)

FIGS. II I2.-Lamna serra, A. S. Woodw.; two teeth, outer (II) and inner (I2) aspects.-U. Chalk; Mont Aimé, Marne, France. (B. M., No. P. 576 r.)

Figs. I3, I4.-Corax falcatus, Agass.; two teeth, outer (I3) and inner (I4) aspects. - Chalk; Kent. (B. M., No P. 2333.)

FIG. 15.-Ditto ; tooth, outer aspect.-Chalk ; Bromley. (B. M., No. 25766.)

FIGs. 16-I8.-Corax pristodontus, Agass.: three teeth, outer aspect.-U. Chalk; Norwich. (B. M., No. 48946 .)

Figs. 19-22,-Corax affinis, Agass.; four teeth, outer $(19,22)$ and inner (20, 2I) aspect.-U. Chalk; Norwich. (B. M., Nos. 3j650, 48947.)

** Unless otherwise stated, the figures are of the natural size. B. M.= British Museum, and the numbers refer to the register of the Geological Department. 
Proc. Geol. Assoc.Vol.XIII.

PI.V.

1.

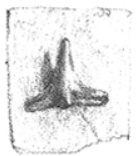

10
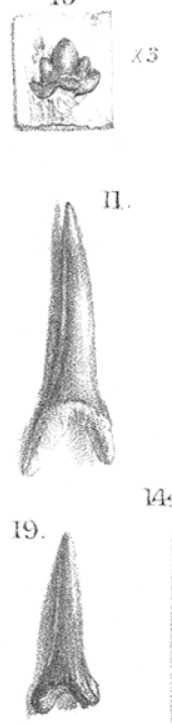

23.
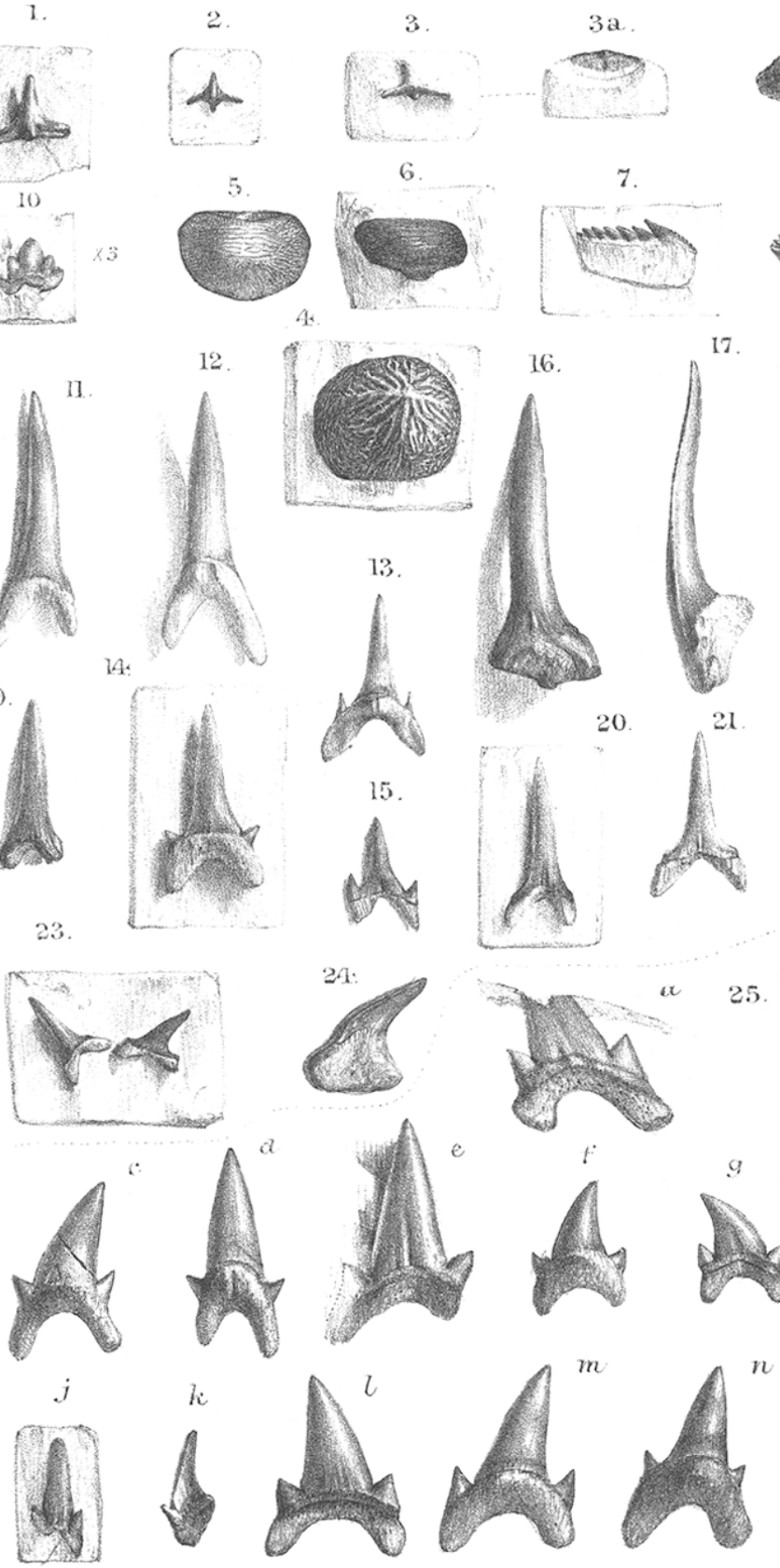

$3 a$.
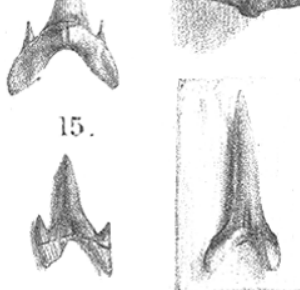

20.
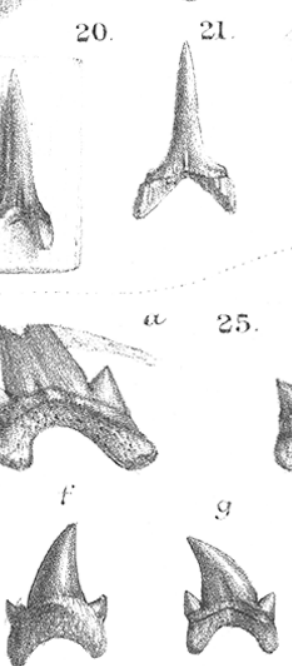

9a. 9.

A)

8.

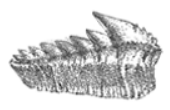

18.
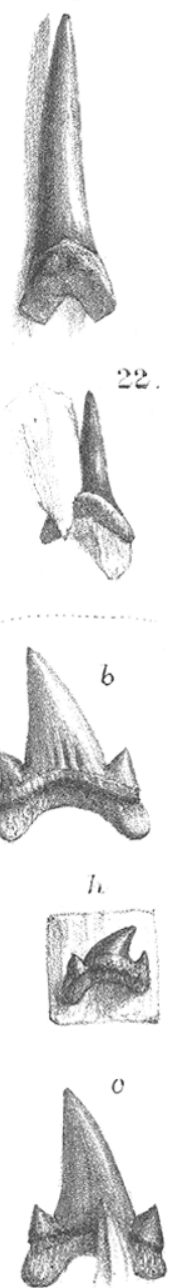

F.H.Michael del et lith. 
Proc.Geol.Assoc.Vol.XIII.
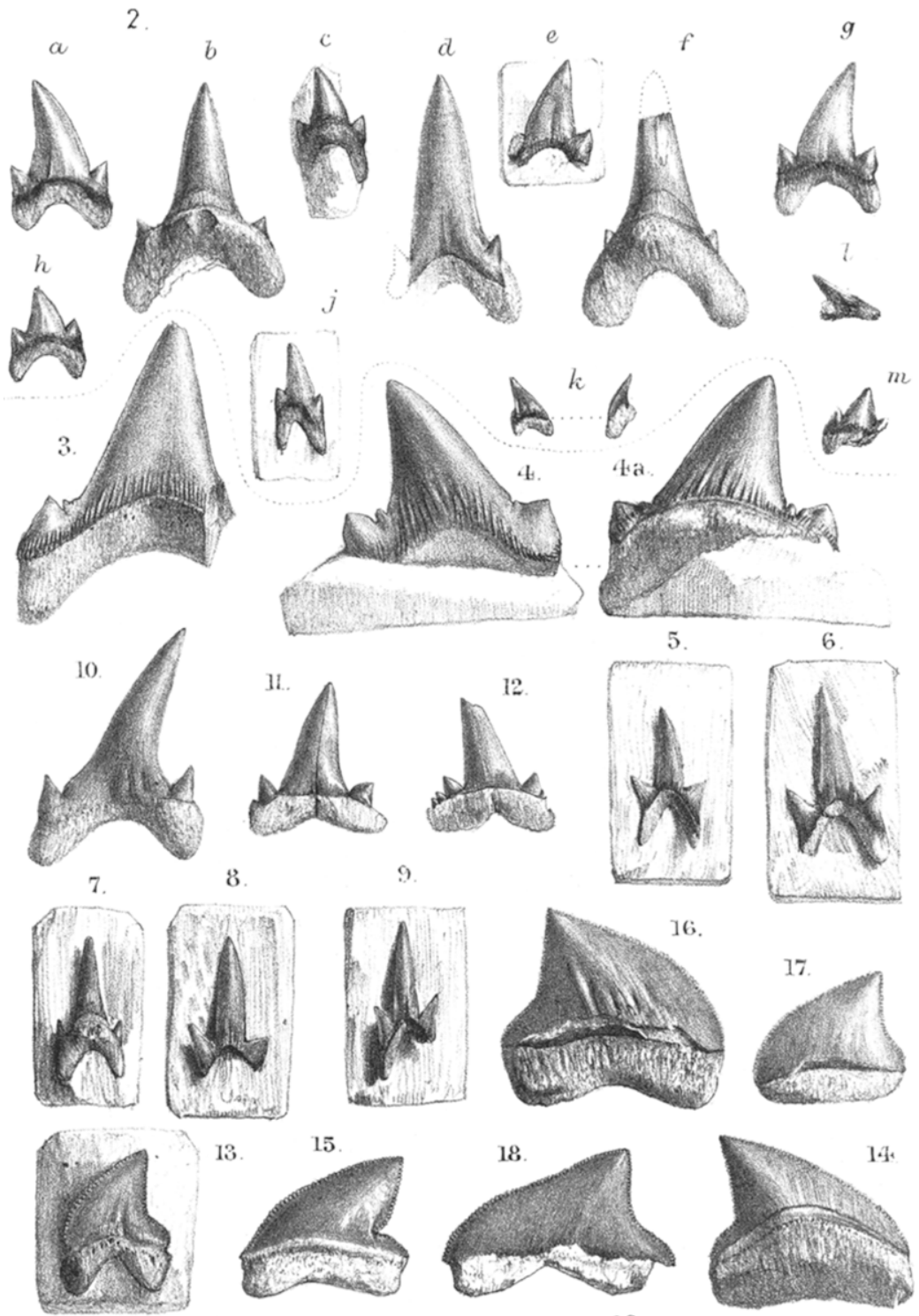

19.

22
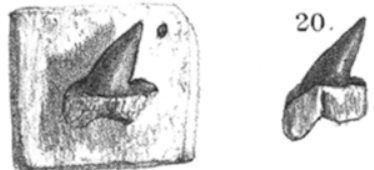

21

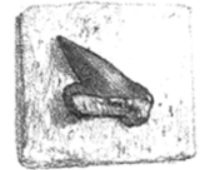

1. $c$

$\times 2$.

証团

F. F.Michael del et. lith.

Mintern Bros . imp.

CRETACEOUS SEIACHIAN TEETH. 